\title{
Russia's Approach to Official Development Assistance and Its Contribution to the SDGs
}

\author{
Yury K. Zaytsep
}

\subsection{INTRODUCTION}

In recent years, Russia's financial contributions to official development assistance $(\mathrm{ODA})^{1}$ have significantly increased and reflected Russia's growing interest in regional and global development cooperation. On 20 April 2014, the Government of the Russian Federation adopted the Concept of the Russian Federation's State Policy, in which national objectives and priorities were officially declared. The concept replaced the previous one, which had been approved in 2007 after Russia's first presidency in the G8 club of global donors. Russia's experience of hosting the G8 summit in 2006 influenced greatly the national ODA agenda and the first concept as well (Larionova 2007).

In spite of the ODA policy agenda-as formulated in the Concept of the Russian Federation's State Policy in the Area of International Development Assistance (2014) (hereafter ODA Concept 2014) -and its strong focus on debt relief, education, and health (Ministry of Foreign Affairs of the Russian

The paragraph was prepared as part of the research work of the state task of the Russian Academy of National Economy and Public Administration (RANEPA).

Y. K. Zaytsev (凶)

Moscow State Institute of International Relations (MGIMO University), Moscow, Russia

Russian Academy of National Economy and Public Administration, Moscow, Russia

(C) The Author(s) 2021

S. Chaturvedi et al. (eds.), The Palgrave Handbook of Development

Cooperation for Achieving the 2030 Agenda,

https://doi.org/10.1007/978-3-030-57938-8_22 
Federation [MoFA RF] 2014), the Russian government still has not fully articulated its national approach to ODA as a result of several issues associated with a lack of convergence of interests at the national level. In terms of its international development cooperation, the Russian government is slowly beginning to cooperate with the Organisation for Economic Co-operation and Development (OECD) Development Assistance Committee (DAC) by providing its ODA statistics. Moreover, it supports a dialogue with the Global South through the BRICS (Brazil, Russia, India, China, and South Africa) format, in which countries identify themselves as emerging donors. All of these trends, as well as the external pressures associated with Western sanctions against Russia and Russian counter-sanctions, challenge current Russian development aid politics.

Moreover, transforming the international architecture of ODA-as agreed upon in the 2030 Agenda for Sustainable Development-along with strengthening the role of new stakeholders, including businesses, present extra challenges for donors, including Russia. The challenges are associated with increasing competition for the markets of developing countries and developing new forms of partnerships.

The Russian government has not yet passed a special national law on compliance with the Sustainable Development Goal (SDG) commitments. However, some of the SDGs coincide with Russia's national priorities introduced by the Presidential May Decree of 2018 (Presidential Press and Information Office 2018) at the regional and country levels. The 2030 Agenda for Sustainable Development, adopted by the United Nations (UN) in 2015, puts a special focus on follow-up and review processes at the national and global levels. Thus, I argue that gradual achievement of the SDGs by 2030 as well as national priorities by 2024 requires strengthening the national ODA monitoring and evaluation (M\&E) system to substantially increase the effectiveness and efficiency of Russian aid abroad as well as contribute towards decreasing excessive levels of bureaucracy.

In this chapter, research on Russia's development assistance is rooted in theoretical fields related to "systemic change" (Humphrey et al. 2014) and "scaling-up" approaches (World Business Council for Sustainable Development 2013). The "scaling-up" approach makes it possible to measure the scale of Russia's engagement in the markets of developing countries in terms of the amount of resources allocated, the number of people reached, geographic footprint, etc. Although economies of scale and returns on political investment are important for the Russian government, scale implies nothing specific about development impact. That is why the "systemic change" approach is useful for explaining how Russia's development cooperation activities align with the national goals and development goals of recipients and the SDGs. It implies transformation in the structure or dynamics of a system, which in turn leads to impacts on the material conditions or behaviours of large numbers of stakeholders. It aims to catalyse change with spillover effects that have broader direct and indirect impacts (Ruffer and Wach 2013). This approach helps to describe the complex nature of Russia's engagement in international development and reveals the issues, challenges, and impacts that have a "systemic change" effect (Harich 2010). 
In order to reveal both the systemic change and scale-up effects of Russia's ODA projects, this chapter discusses M\&E issues. Moreover, given the difficulties in achieving the SDGs, special emphasis is placed on changes that concern the scaling-up and systemic change approaches of Russia's ODA projects. Last but not least, Russian businesses are becoming increasingly empowered players that also contribute to systemic change and broadening the scale of Russia's ODA projects. All above-mentioned issues are addressed here from the perspective of both theoretical approaches and with the recognition that systemic change in progress is not straightforward, since it involves changes beyond just tangible outputs (Thorpe 2014).

Moreover, due to the changing nature of Russian ODA, its national projects are often associated with contested cooperation in order to overcome the challenges mentioned above. Contestation is present both at the national and international levels. At the national level in Russia, controversies have arisen among national governmental bodies, such as the Ministry of Finance (MoF) and the Ministry of Foreign Affairs, over Russia's financial and political influence in the context of ODA, which could potentially result in the creation of new national institutions that independently implement Russia's ODA policy. At the international level, contestation is due to Russia's participation in new institutions (New Development Bank, Asian Infrastructure Investment Bank, etc.) as a result of competition with international donors over the markets of developing countries.

To sum up, the chapter looks at Russia's evolving approach to ODA policy implementation. It places the emphasis on the background, the established modes of engagement by key sectors and channels, as well as new challenges concerning the implementation of the SDGs, such as Russia's M\&E system and its engagement with businesses, which is also a challenge to the current ODA system.

\subsection{Russia as a Global Donor}

The Soviet mode of ODA engagement was mainly associated with the scalingup approach, whereby the Soviet government injected financial resources into socialist countries and low-income economies for their political support in the international arena (Bartenev and Glazunova 2013). Russia's modern economic history can be characterised by the ups and downs regarding the significance ascribed to Russia as a partner in international development cooperation. In the 1990 s, during a tumultuous transition period, Russia was included in the DAC recipient countries list and provided concessional credits to support its economy. In 1997, Russia was invited to join the G7/G8, in which it remained a member until 2013. In 2006, Russia officially became a global donor after accepting the presidency of the G8 and hosting the G8 summit in Saint Petersburg, where global donors made a set of commitments on fighting global poverty in such areas as education, energy, and health. This required the Russian government to adjust its ODA approach to the international development agenda. As a result, the process invoked a systemic transformation of national institutions for ODA policy implementation. 
As was mentioned above, in 2007, immediately following Russia's G8 presidency, a decree on the "Concept of Russia's Participation in International Development Assistance" was approved by the Russian president (MoFA RF 2007). The 2007 decree made special reference to Russia's international commitments such as the Millennium Declaration, the Monterrey Consensus, and the Paris Declaration on Aid Effectiveness, among others. It reaffirmed Russia's multidimensional approach to development policy going beyond the previous focus on debt relief commitments, which Russia had made at the G8 summit in Gleneagles in 2005.

Russia has been gradually building up and broadening its international development assistance programmes: from about \$100 million in 2004 to a peak of almost $\$ 1.3$ billion annually by 2016 (Fig. 22.1). This is primarily associated with the government's efforts to create a national ODA system according to the geographical and sectoral priorities of the ODA Concept 2014. Although the amounts are modest by comparison with other donors, and also in relation to Russia's gross domestic product, they are nevertheless significant enough, especially at a time when the Russian economy is under severe stress from international sanctions, which undermine the national economy and decrease the overall level of governmental expenditures. For instance, ODA expenditures are comparable to the budgets of 10 of Russia's poorest regions and could be used to implement the Russian government's social commitments.

During the 2014-2017 period, which coincided with external and internal political and economic crises as a result of the imposition of Western sanctions against Russia and its counter-sanctions, the Russian Federation continued to strengthen its position as an international donor, supporting the annual financing of programmes and projects in the field of international development assistance at a level above $\$ 1$ billion. A special priority was maintained with

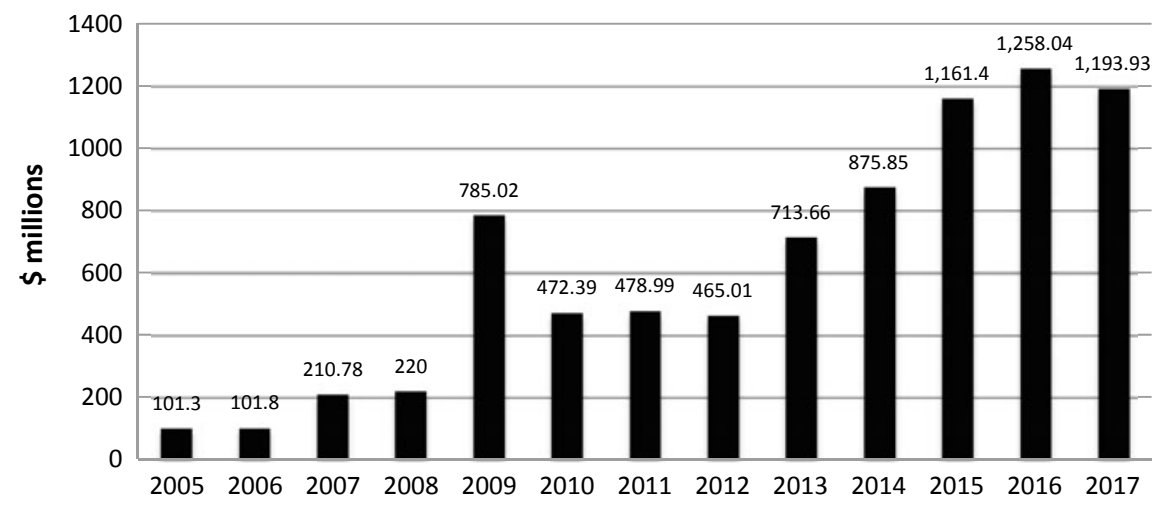

Fig. 22.1 Official development assistance provided by the Russian Federation in the period from 2005 to 2017 (\$ millions) (Source Based on data provided by the OECD-DAC and the MoF of Russia [Knobel and Zaytsev 2018]) 
respect to the formation of a zone of good neighbourliness in the framework of economic support for countries in the Commonwealth of Independent States (CIS) (Knobel and Zaytsev 2017). Moreover, in 2014, after Crimea's annexation, a new presidential decree was issued for "Russia's State Policy in the Area of International Development Assistance" (MoFA RF 2014). The emphasis was kept on international commitments made between 2007 and 2014. The focus on supporting sustainable development outcomes was not changed. However, the ODA Concept 2014 reflected more active participation by Russia in ODA and referred to the significant roles of academia, civil society, and business. Moreover, a focus on the M\&E component was also added. This trend is associated with the systemic change that the Russian government intended to make in the light of its new approach to foreign policy, which assumed a focus on enhanced cooperation with its Eastern neighbours.

According to recent statistics, in 2017 , Russia allocated $\$ 1.19$ billion for its ODA, which was 5 per cent less than in 2016. This correlates with the general downward trend of the global level of ODA, which, in 2017, was 0.6 per cent lower than the previous period and amounted to $\$ 146.6$ billion (Organisation for Economic Co-operation and Development [OECD] 2017). The volume of Russian ODA does not exceed 0.1 per cent of its gross national income, whereas one of the UN's objectives for development financing is the annual allocation of donor assistance at the level of 0.7 per cent of gross national income (OECD 2019).

The enforcement of the ODA Concept 2014 also coincided with economic turmoil. The internal and external challenges for the Russian economy in the 2014-2017 period were mostly associated with sanctions, with the estimated impact for the Russian economy being between 1.0 per cent and 1.5 per cent of gross domestic product per year, and foreign direct investment outflow exceeding $\$ 150$ billion (Central Bank of the Russian Federation 2018). Despite the economic decline, Russia managed to maintain its annual development aid allocations above \$1 billion. This reflects both the scale-up and systemic changes of Russia's ODA policy. The "scale-up" is primarily associated with the resilience of the government to increase the volumes of ODA on an annual basis, whereas the "systemic change" effect of ODA programmes was ensured by the Presidential May Decree of 2018. This decree included the M\&E component and a new approach to foreign policy that reinforces the new SDG agenda, all of which contribute to the transformation of the aid planning and aid delivery mechanisms.

\subsection{Distribution of Russian ODA by SECTOR AND ChanNel}

Despite a wide range of priority sectors identified in Russia's ODA Concept 2014, the current practices concerning Russian ODA generally relate to multilateral and bilateral modes of engagement and are associated primarily 
with humanitarian aid and debt relief. The analysis of these priorities reveals the scope of Russia's engagement in international development cooperation and illustrates how these areas of engagement contribute to systemic change. Moreover, understating the current instrumental and sectoral modes of engagement in ODA helps to identify national priorities associated with achievement of the SDGs and M\&E system establishment.

\subsubsection{Multilateral Aid}

The current mode of engagement for aid distribution is associated with an increase in the volume of bilateral aid. The main motivation of the Russian MoF is to raise the level of Russian aid effectiveness by developing bilateral channels with the Russian government, which could then exercise greater control over it.

However, in 2012, bilateral aid flows were almost at the same level as those for multilateral financing-and even in excess of them in 2013. Moreover, in the 2014-2017 period, the share of bilateral and multilateral assistance increased from 28.2 per cent in 2014 to 39 per cent (2016) and 38.5 per cent (2017), respectively, of total ODA (Fig. 22.2). This indicates the reliance of the Russian government on using international institutions as mechanisms for the provision of ODA.

The key multilateral partners for Russia in 2017 were UN institutions (\$140.88 million), the World Bank (\$61.3 million), and regional development banks (\$225.12 million) (Table 22.1).

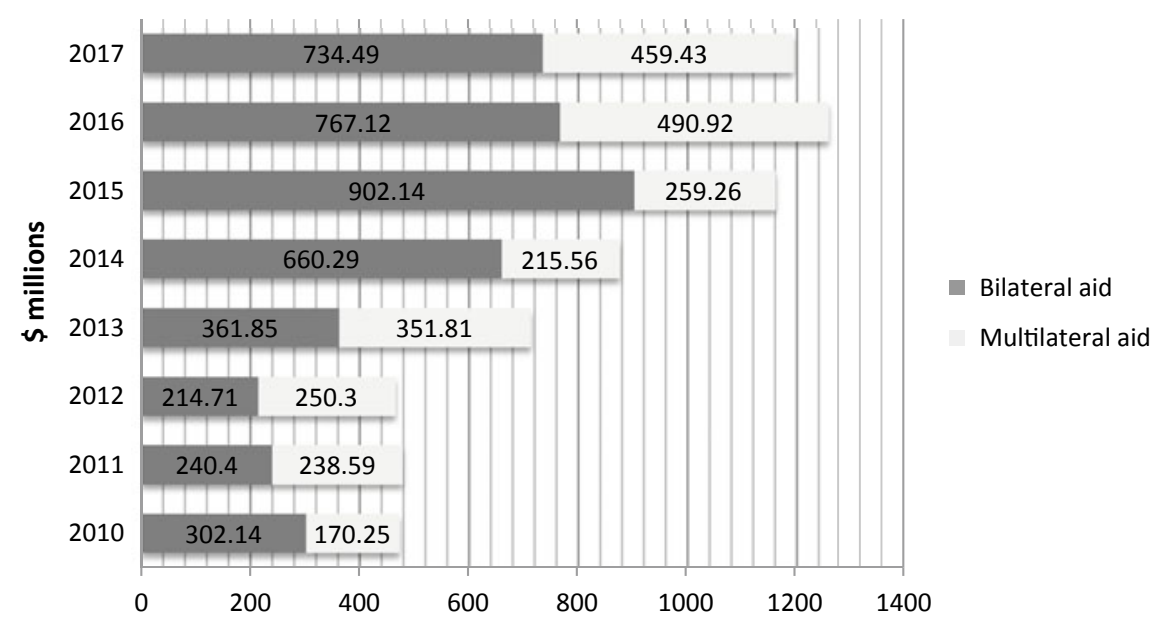

Fig. 22.2 Distribution of Russian ODA to bilateral and multilateral assistance (\$ millions) (Source Based on data provided by the OECD-DAC and the MoF of Russia [Knobel and Zaytsev 2018]) 
Table 22.1 The amount of financial participation by Russia in international development institutions in 2017

\begin{tabular}{lc} 
International institute & $\begin{array}{c}\text { The volume of financial } \\
\text { participation by Russia } \\
\text { (\$ millions) }\end{array}$ \\
\hline UN institutions & 148.22 \\
World Bank institutions (IDA, & 61.3 \\
IBRD, IFC, IIGA) & \\
Regional development banks & 225.12 \\
Montreal Protocol (1987) & 3.55 \\
Other international institutions & 17.65 \\
Total & 455.83
\end{tabular}

Source Based on data provided by the OECD-DAC and the MoF of Russia (Knobel and Zaytsev 2018)

Despite the statements made in the framework of the spring annual meetings of the World Bank and the International Monetary Fund in 2018 on Russia's abstinence regarding the recapitalisation of the World Bank in the amount of $\$ 13$ billion, the Russian government continues to use the bank's tools to implement aid programmes ("Russia and the United States" 2018). At the World Bank, the Russian Federation finances projects within the framework of the 21 established trust funds (World Bank 2019). The total cash contributions amounted to $\$ 62$ million for the 2013-2017 period, earning Russia 25 th place in the rankings of trust fund donors by the International Bank for Reconstruction and Development (IBRD) and the International Development Association (IDA) (World Bank 2018). As for the regional development banks, the main priority in 2017 was given to those that were implementing their projects in the Eurasian space (Knobel and Zaytsev 2018). The focus was set on the Eurasian Development Bank and its projects concerning regional infrastructure development (SDG 9) (Eurasian Development Bank 2017).

\subsubsection{Bilateral Aid}

As a part of its bilateral cooperation, Russia is implementing its scale-up approach and continues to focus on providing assistance to the CIS countries. In the cases of many post-Soviet countries, Russia became one of the largest donors. For example, according to the Russian Federal State Statistics Service (Rosstat) under the President of Tajikistan, Russia's share in overall development assistance amounted to 19.8 per cent ("What assistance does Russia provide" 2017). According to the deputy foreign minister, Alexander Pankin, Russia's priority regions in 2017 also included countries from Latin America, Africa, and Asia ("The volume of Russian assistance" 2018).

Yet, the majority of Russia's bilateral international development assistance is focussed on specific countries that are partners, friends, or neighbouring countries of Russia. Such country-specific programmes account for 40 per cent 
of all programmes and 80 per cent of all of Russia's current ODA financing (Annex A). The most prominent recipients are Kyrgyzstan, Tajikistan, Cuba, North Korea, Nicaragua, Guinea, Serbia, Mozambique, Syria, and Armenia, which together account for 95 per cent of Russian ODA directed at specific countries (Knobel and Zaytsev 2017).

Currently, Russian bilateral aid focusses mainly on debt relief (SDG 17), the environment (SDG 13), rural and infrastructure development (SDG 9), energy (SDG 7), health (SDG 3), water and sanitation (SDG 6), as well as budget support (SDG 17). Russia uses its multilateral mechanisms through the World Bank or the World Food Programme to assist CIS countries, while placing a special focus on the Kyrgyz Republic, Tajikistan, and Armenia for infrastructure development and the provision of food security. These activities are in line with Russia's specific national objectives in the Eurasian economic space (MoFA RF 2014) associated with economic integration at the sectoral and country levels.

As was mentioned above, Russia is also cooperating with the other BRICS countries. However, unlike the other members, it is not a part of the "Global South" nor a participant in South-South cooperation. BRICS countries do not have a common approach to ODA politics. ODA is one of the policy areas in which the only format of engagement for BRICS countries is dialogue.

\subsubsection{Humanitarian Aid and Debt Relief}

The ODA Concept 2014 identifies health, education, energy, and agriculture (food security) as the basic sectors for Russian aid provision. The main reasons for this are strong national competencies and, as a result, comparative advantages for Russia as a global donor. However, in practice, the bulk of Russian ODA is provided as humanitarian aid and debt relief. According to the Federal Customs Service, in 2017 Russia sent goods as humanitarian aid worth \$23.3 million, which is 2.2 times more than in 2016. The key recipient of Russian humanitarian aid was the Syrian Arab Republic. The share of the charity aid provided to it made up 84 per cent of the total volume of Russian humanitarian aid, which, in value terms, is about $\$ 19.6$ million (Federal Customs Service 2018). A significant share of Russia's ODA continues to be debt relief to developing countries. In 2017, the amount of debt forgiveness to this group of states amounted to $\$ 424.94$ million (35.6 per cent of total ODA). For example, in June 2017, Kyrgyzstan had \$240 million of its debt written off ("Russia has written off Kyrgyzstan's debt" 2017). This mechanism remains a traditional form of Russia's ODA. In 2017, for example, the Government of Russia issued a loan to the Republic of Belarus that amounted to about $\$ 700$ million over a period of 10 years ("Belarus received from Russia a loan" 2017).

Cuba offers a special case in Russia's debt relief politics. On 7 June 2016, a special version of the Russian-Cuban intergovernmental agreement (of 25 October 2013) (Agreement between Cuba and Russia 2013) was agreed as a 
tool for the co-financing of projects implemented by Russian companies in Cuba (Ministry of Finance 2013). Funds in a special account are used to finance investment projects in the Republic of Cuba-including projects in the field of environmental protection-and selected by the Cuban Communist Party in accordance with the National Plan for Economic and Social Development of Cuba. As of 1 October 2017, the amount of funds deposited in a special account was $\$ 1.06$ billion. This means that the Cuban government can attract these resources to finance its project with participation by Russian businesses. According to the agreement, the Cuban customer and the Russian contractor conclude a contract, under which the contractor implements the project approved by the parties (perform work, provide services, deliver goods, etc.). This also assumes public-private partnerships (PPPs), as long as the Cuban customer is represented by governmental bodies.

As an advantage, it provides access to a large amount of additional sources of project financing, reducing the need for loan funds. What is more, it provides a possibility for payment in the local currency for expenses incurred during the project. As a condition, the Government of Cuba should receive "priority project" status for such activities and include them in the National Plan for Economic and Social Development of Cuba. The disadvantage is that the Cuban government is only able to implement these projects in conjunction with Russian businesses. This mechanism is more about scale and return on investment rather than its importance for businesses. However, over a period of time, infrastructure and capacity-building project outputs may bring about systemic transformation.

Currently, the mechanism is also being used for financing parts of the "advanced" payments on the Cuban side for preparatory, construction, assembly, and other work being carried out by Cuban companies. This work is performed under existing contracts that are implemented through intergovernmental agreements on the provision of Russian state export credits (for projects such as the modernisation and construction of the Maksimo Gomez TPP East Havana and the metallurgical plant Antilla de Acero im José Martí).

It should be noted that the actual value of ODA provided by the Russian Federation exceeds the amounts published in OECD statistics. The first reason for this is the provision of assistance to countries that are not on the OECDDAC list of beneficiaries. Russia continues to support the socio-economic development of South Ossetia, which is still considered by the international community to form part of Georgia. For example, the Russian government has allocated RUB 600 million for the construction of an operational-surgical complex at the Republican Hospital. This was a project included within the investment programme that relied on Russian financial assistance for the 20152017 period (Sineva 2018). Moreover, the Russian Federation, like other OECD-DAC countries, also allocates funds to combat international terrorism and provides military assistance. However, these areas of assistance are not taken into account in ODA statistics (Zaytsev 2013). 
Thus, an appropriate accounting of Russian ODA would make it possible to provide more accurate assessments of the scale of Russia's official engagement into the markets of developing countries through bilateral and multilateral channels. Moreover, humanitarian aid and debt relief often reflect only the quantitative side of international development engagement. In order to make further qualitative judgements on the systemic change of Russian ODA and its impact, an evidence base is required. However, Russia's ODA politics currently lack substantive and qualitative impact assessments due to a concrete absence of ODA M\&E practices.

\subsection{Monitoring AND Evaluation}

Current trends reveal that Russia's ODA policy places a greater emphasis on tracing the government's actions in the field of development cooperation in order to raise the efficiency and effectiveness of Russian aid. Moreover, in the light of scarce budgetary resources, monitoring external and internal governmental policy implementation could raise Russia's accountability standards. That is why elaborating institutional models and establishing a national M\&E system is essential, especially for external policies such as ODA (Boehmer and Zaytsev 2018). Moreover, as was mentioned above, M\&E systems help to trace the progress of "systemic change" and evaluate the "scope" of engagement to fight global poverty.

From an expert point of view, there are several reasons for establishing an ODA M\&E system in Russia. ${ }^{2}$ The first reason is the provision of information to the public and the government, especially in time of budget constraints. The efforts should be undertaken in conjunction with a communication strategy, which requires the development of a clear narrative that speaks to key audiences and is based on factual data, combined with information on Russia's impact that stakeholders can relate to for further decision-making. This could take the form of an annual institutionalised report to the government and the public in the form of an easily understood brochure. These reports should incorporate simple indicators on what has been done on the global and country levels (Boehmer and Zaytsev 2018). They should be measurable and the data should be readily available. The successful examples of establishing ODA M\&E systems are usually associated with the practices of the United Kingdom, Germany, Canada, Australia, etc. (Boehmer and Zaytsev 2019), where the efficiency of ODA projects is assessed against "systemic change" criteria.

The second reason is accountability to the Governmental Commission on International Development Assistance by providing data on Russia's ODA. ${ }^{3}$ The main purpose of reporting to the commission is to show the value for money and the rationale for the spending of ODA.

The third reason is associated with G20 accountability, which assumes preparation of the National Action Plans to achieve the SDGs. As a member of the G20, Russia is committed to providing annual reports showing compliance with SDG targets. The international commitment coincides with Russia's 
national priorities on achieving the SDGs, which is reflected in the Concept of the Russian Federation's State Policy in the Area of International Development Assistance (MoFA RF 2014). Moreover, the usage of SDG indicators could strengthen the national ODA M\&E system as well as optimise the efficiency and effectiveness of Russian development aid projects. Thus, SDG reporting for the G20 could be a part of national efforts towards ODA M\&E.

According to Russia's MoF, Russia is accountable to the G20 and is in charge of preparing the National Action Plans to achieve the SDGs. ${ }^{4}$ The report is supposed to be composed of two parts. The first part relates to national actions on internal politics. The second part deals with external actions associated with achievement of the SDGs. For this purpose, mainly SDGs 5 and 6 will be reported on at the G20. Many of the SDGs have crosscutting points, and an SDG-Millennium Development Goal mapping should be done for the purpose of assessing the progress made.

Despite the inclusion of some M\&E elements in the 2014 Presidential Decree, a little progress had been made in establishing an ODA M\&E system. In part, this was due to the composition of Russia's aid with relatively few bilateral projects that would constitute a portfolio with the potential to draw lessons. Other reasons were more political, such as the decision-making process for the allocation of funding, which was associated with the divergent perspectives of the Ministry of Foreign Affairs and the MoF.

Shortly after the adoption of the 2014 Presidential Decree, the MoF was given full authority to develop a national ODA M\&E system. However, given that Russia does not have a consolidated development assistance budget that is under the responsibility of a single line ministry, developing a national M\&E system would inevitably involve cross-ministerial coordination and agreement on the key parameters (Boehmer and Zaytsev 2018).

The MoF first turned to other "Southern donors", including Brazil, to gain a better understanding of balancing domestic demands and international best practices. At the same time, multilateral organisations such as the World Bank and the United Nations Development Programme provided support in aligning national objectives with global agreements and practices. Although the 2014 Presidential Decree contained a long list of priorities, the MoF was unable to reach an agreement within the government on the purpose of the future M\&E system. Pressure to make progress, however, continued to mount, with parliament expecting the Russian government-and specifically the MoF-to provide annual progress updates (Boehmer and Zaytsev 2018).

The emphasis on strengthening national ODA M\&E systems has become one of the main prerequisites for the gradual achievement of the SDGs by 2030. The 2030 Agenda for Sustainable Development, adopted by the UN in 2015 , puts a special focus on follow-up and review processes at the national and global levels. It should be informed by global and country-led evaluations and data that is high-quality, accessible, timely, and reliable (United Nations [UN] 2015) in order to inform stakeholders on the systemic changes and the scale of change. 
With the launch of the SDGs, many governments are actively working to consider how they will address the SDG indicators and targets. It often makes them reconsider the main principles of the national M\&E systems for addressing this challenge. Given that the Russian government is at the very early stage of establishing a national ODA M\&E system, taking the SDGs into consideration could be a part of the process. This would also contribute towards raising the level of transparency of Russia's efforts in the field of international development cooperation. What is more, most of the SDGs assume long-lasting systemic change effects. To reveal these effects in the future, the M\&E system should be created as fast as possible. Through the monitoring and assessing of appropriate SDG targets, the governmental bodies would be able to track their incremental efforts towards systemic change.

\subsection{Russia's ODA Policy ANd the SDG Agenda}

The SDGs have become a new challenge for the international community, especially in the light of the changing development agenda. Each SDG is subject to comprehensive efforts towards achieving and maintaining them, with all 17 SDGs being interconnected and interrelated. The relationships between the goals can be even more complex. Each goal is connected to other goals and sub-targets in different, often context-dependent ways (UN 2015). Moreover, the introduction of the SDGs into Russia's ODA politics addresses its systemic change approach, with spillover effects among the goals and targets that have direct and indirect impacts (Ruffer and Wach 2013). Currently, the systemic change with respect to SDG implementation is about altering functions and structures associated with Russian institutions and legislation. They relate primarily to ODA M\&E system creation and the agency responsible for ODA provision.

In December 2016, a meeting of the State Council was held on the issue "On the environmental development of the Russian Federation in the interests of future generations" (Presidential Press and Information Office 2016). The government was instructed to consider "as one of the main goals of Russia's transition to a model environmentally sustainable development" to define and use a system of indicators for sustainable development-mechanisms for achieving the goals of the country's environmentally sustainable development policy by 2030 , and thereafter by 2050 . Other assignments for the government included: (1) the provision of the definition of target indicators of the energy efficiency of the economy and the implementation of a set of measures to increase it, including the development of renewable energy sources; (2) consideration of the impact of introducing environmentally sustainable development mechanisms.

The monitoring of Russia's achievement of the SDGs has been included in the Federal Statistical Work Plan since 2017 (Resolution of the Government of the Russian Federation 2017). Rosstat (2019) was assigned as the responsible body for the development of a national set of indicators of SDGs 
for Russia for their further implementation in state strategic documents. ${ }^{5}$ It also coordinates the collection and provision of statistical information on SDG indicators to international organisations (Order of the Government of the Russian Federation 2017). In total, 90 SDG indicators have been collected, including 54 indicators ( 60 per cent) by Rosstat and 36 indicators ( 40 per cent) by ministries and departments. In 2017, the Rosstat portal created a "Sustainable Development Goals" section for downloading statistical information on monitoring the implementation of the SDGs at the national level (Rosstat 2015). Thus, the SDGs are shared by the Russian government with respect to its internal and external politics.

At the national level, the SDGs are partly expressed by a decree of the President of the Russian Federation "On the National Goals and Strategic Objectives of the Development of the Russian Federation for the Period up to 2024" (Presidential Press and Information Office 2018). The May Decree of 2018 sets strategic tasks for the government and determines the indicators for the results that are expected to be achieved in six years, thereby achieving the tasks of the SDGs.

The official version of the Presidential May Decree of 2018 encompasses nine national goals in the fields of demography, poverty eradication, income increases, housing improvements, technology development, digital economy, economic growth, and export expansion (Table 22.2).

From this, it can be seen that the SDGs are becoming priorities for Russia's social and environmental development (Presidential Press and Information Office 2016), with Rosstat having become the main stakeholder in identifying and monitoring the targets at the national level (Resolution of the

Table 22.2 List of national goals of the Presidential May Decree of 2018

a. ensuring sustainable natural growth of the population of the Russian Federation;

b. increase in life expectancy to 78 years (by 2030-up to 80 years);

c. ensuring a steady growth in the real incomes of citizens as well as an increase in pension amounts above inflation levels;

d. halving the level of poverty in the Russian Federation;

e. improvement of living conditions for at least 5 million families annually;

f. acceleration in the technological developments of the Russian Federation, and an increase in the number of organisations implementing technological innovations, up to 50 per cent of their total number;

g. ensuring the accelerated introduction of digital technologies in the economy and the social sphere;

h. contributing to the Russian Federation so that it becomes one of the five largest economies in the world, ensuring economic growth rates that are higher than global ones while maintaining macroeconomic stability, including inflation, at a level not exceeding 4 per cent;

i. job creation in the basic sectors of the economy, primarily in the manufacturing industry and the agro-industrial complex, for a highly productive export-oriented sector that is developed on modern technologies with highly qualified personnel.

Source Presidential Press and Information Office (2018) 
Government of the Russian Federation 2017). However, it is still necessary to supplement the country's national strategic planning system for ODA with its Sustainable Development Strategy, as well as with the SDGs in order to contribute towards their achievement by 2030 (Bobylev and Grigoriev 2015).

The political goals for Russian ODA are also correlated with the SDGs and can be classified at the global, regional, and recipient country levels. Traditionally, Russia's priorities as a global actor covered the areas where the country possessed comparative advantages, such as health, education, and energy, as well as food security. All these areas are related to facilitating sustainable socioeconomic development in partner countries, including post-conflict countries (SDG 1). Other goals of the ODA Concept 2014 at the global level-such as limiting the consequences of natural disasters or establishing a stable and equitable world order based on universally recognised norms of international law and relations between countries - can also easily be mapped (SDGs 11 and 17).

At the regional level, Russia's priorities are mostly associated with facilitating the integration processes among the CIS countries, with particular emphasis on the development of trade and economic cooperation (SDG 9) (Knobel et al. 2019). With respect to other neighbouring countries, Russia is primarily keen on facilitating the elimination of potential points of tension and conflict and sources of drug trafficking, international terrorism, and organised crime, as well as preventing their occurrence (SDG 16) (MoFA RF 2014).

At the level of recipient countries, the interests related to Russian ODA very often coincide with its global and regional priorities, so its ODA policy aims at overcoming the barriers at the national level in order to implement these priorities (Boehmer and Zaytsev 2018). Russia's national interest in supporting developing countries is translated into practice by boosting economic activity, creating conditions to involve the poorest groups of the population in economic activities (SDG 6 and 7), and providing access to vital resources, primarily water and electricity (SDG 9). In the case of Russia's Eurasian economic integration policy, all these measures help the recipients to improve conditions for their trade and investment activities in order to enhance their proactivity in the Eurasian economic space (Knobel et al. 2019).

Another angle of Russian national interest in ODA politics relates to the support of global partnerships (SDG 17), which is primarily associated with strengthening national health systems and social safety nets (SDG 3), raising the quality of education (SDG 4), and supporting efforts on post-conflict peace-building (SDG 16) (MoFA RF 2014). The partnerships are associated with institutional cooperation focussed in these areas at the international level in the framework of the G20, the UN system, etc.

Overall, most of the priority areas of Russia's ODA policy at the global, regional, and national levels correlate with the relevant SDGs. Given that the achievement of development objectives is not associated merely with a particular SDG or several SDGs, it is important to note that the priority 
areas and relevant objectives of Russia's ODA engagement should be mutually reinforcing and complement each other. Thus, the national priorities for Russia's ODA policy should result from considerations about the provisions of the ODA Concept 2014, the relevant SDGs discussed above, as well as the perspectives of stakeholders contributing to the implementation of ODA projects (such as the Ministry of Foreign Affairs and other sectoral federal governmental bodies, as well as civil society and business).

For a successful implementation of the objectives of the SDGs, it is necessary to adapt the SDG indicators at the national level. Existing tasks and activities within the framework of national socio-economic development programmes need to be analysed and compared with global goals and objectives to assess compatibility or conflicts as well as gaps in the content of national documents. Given the complex hierarchy of Russia's ODA priorities at different levels, it is essential to focus on areas where national interests coincide as well as on regional objectives and the SDGs as global priorities. So, in narrowing down the priority areas for the purposes of developing a simple M\&E system, I suggest considering those areas where Russian national interests coincide directly with SDGs that support recipient countries. Those would be the goals of zero hunger (SDG 2), clean water and sanitation (SDG 6 ), affordable and clean energy (SDG 7), decent work and economic growth (SDG 8), as well as industry, innovation, and infrastructure (SDG 9) (Boehmer and Zaytsev 2018).

\subsection{Russian Businesses AND ODA}

Russian businesses have been represented in the markets of developing countries since Soviet times. In essence, the economic assistance of the USSR served as a corporate social responsibility (CSR) programme for Soviet enterprises operating there. This form of cooperation was aimed at overcoming the negative externalities associated with the work of Soviet industrial enterprises, as well as at strengthening their positions. For ideological reasons, socially oriented programmes that accompanied the work of Soviet organisations could not conceptually and meaningfully intersect with the programmes of companies in capitalist countries. Nevertheless, in fact, they had a large number of points of intersection with the CSR projects of Western partners (Zaytsev 2018).

Notwithstanding that the current role ascribed to businesses as development actors goes far beyond their CSR practices, due to the lack of information on Russian private development engagement, this chapter only relies on open CSR data that is published by Russian companies as a part of their participation in the Global Reporting Initiative. The expenditures of Russian companies for external CSR practices are usually associated with development objectives in the field of infrastructure and human development.

The share of Russian businesses' foreign direct investment in the poorest countries of Africa, Latin America, and South-East Asia is still quite low. For 
example, the figure is less than 8 per cent in sub-Saharan Africa and less than 1 per cent in the Middle East and North Africa (RAS Institute 2014). In emerging and fast-growing markets, Russian investors are surpassed by their US, Chinese, EU, and Australian competitors in Africa, Latin America, and South-East Asia. The main reasons predominantly concern the relatively high levels of competition and support from national governments, which-in the cases of the United States and the European Union-often have more diversified and effective mechanisms of support. For example, in 2015, US companies spent more than $\$ 41.5$ million for CSR projects in the African region. At the same time, Nigeria (\$5.41 million) and Egypt (\$6.14 million) are among the largest recipients of social investments (Chief Executives for Corporate Purpose 2016).

Russian companies are also represented in the region in the mining and services sectors, where CSR programmes accompany business processes. However, Russian companies' expenditures for external CSR are substantially lower. For instance, Lukoil Overseas implements its projects in Egypt, Ghana, Côte d'Ivoire, and Iraq. According to 2015 data, Lukoil Overseas spent more than $\$ 5$ million for projects aimed at ensuring the company's CSR in foreign countries (Lukoil Overseas 2011).

However, the Russian private sector has an extended portfolio of CSR projects. CSR programmes implemented by Russian businesses abroad vary substantially, depending on the specifics of the business and terms of funding. For example, businesses from the industrial sector of the economy put special emphasis on infrastructure projects and the development of human capital and local communities, whereas businesses from the financial sector are implementing CSR projects, which mostly focus on environmental and social issues (Zaytsev 2018).

Russian businesses put a special emphasis on the projects that affect local communities when implementing CSR programmes. A prime example is the work of Russian companies from the mining sector, such as Alrosa, Lukoil Overseas, Rusal, Gazprom, and Rosneft, in the markets of developing countries and countries with rapidly growing economies.

Lukoil Overseas has become Russia's largest private company in terms of assets, sales, and spending on social-oriented projects in Africa, Latin America, and the Middle East. The company is ranked among the 10 largest nonfinancial transnational corporations that are represented in the markets of developing countries and countries with economies in transition.

One of the largest projects of the company in Africa is "Meleiha" (Western Desert), which will be implemented under the terms of a concession until 2024. The company owns a 50 per cent stake in the project. The Egyptian government and the Egyptian oil company EGPC are the holders of the rest of the shares. One of the conditions for the concession was the implementation of socially oriented projects aimed at ensuring the interests of local communities and the development of infrastructure. The company has implemented its CSR projects in Sierra Leone, Ghana, and areas around the Gulf of Guinea as part of 
its business activities. Most of the projects have focussed on the development of local communities.

The mining company Rusal is also among the key representatives of Russian companies implementing CSR projects in foreign countries where they operate, such as Guinea, Nigeria, Guyana, and Jamaica. The company is also leading in terms of financing social projects, which, for 2013, amounted to about $\$ 10$ million (Rusal 2013a).

The social activities of the company relate to participation in infrastructure projects. In the city of Fria (Guinea) over the last 10 years, the company has been carrying out the construction of artesian wells, public schools, as well as the reconstruction of the city mosque and the Catholic Church. In Guyana, the company built a plant for the purification of drinking water for the Hururu village and carried out the electrification of the village-having supplied the electricity through the generating capacity of its plant (Rusal 2013b).

CSR practices have become an inevitable part of business activity portfolios and are often implemented as part of a corporate management programme. On the one hand, the practices are in line with governmental efforts to provide public goods. On the other hand, they do not always advance the core targets of the SDGs, but they do contribute to economic development and growth.

The integration of Russian businesses into the system of global economic relations means deeper involvement in value chains, which, in turn, suggests expanded production in developing markets, depending on the availability of critical production factors, which contribute to both scale and change. However, political risks and the inefficient system of state support to capital exporters - with a focus on companies with government participation-considerably complicate the invasion of foreign developing markets by Russian businesses. However, participation by Russian businesses in national ODA projects could substantially reduce such risks. What is more, commercial private capital could contribute towards financing the SDGs through blended mechanisms, with Russia as the official donor. Overall, development and related SDG projects are often not bankable for businesses. Consequently, private capital could be an alternative source to "turn the billions into trillions".

There are several mechanisms, including PPPs, that could increase the involvement of the Russian private sector in state ODA projects. PPPs have become an integral part of the SDG agenda and contain an enormous potential to contribute to the achievement of SDGs 8,9 , and 17 , in particular.

Moreover, some Russian companies have already indirectly integrated the SDGs into their day-to-day activities. According to the Russian Union of Industrialists and Entrepreneurs, about 200 companies have implemented more than 500 projects to overcome social and environmental challenges, thereby contributing towards the achievement of the SDGs. Moreover, 25 of these companies-working in fields such as energy, oil and gas, metallurgical and mining, agriculture, and telecommunications-have streamlined their social and environmental practices with the SDGs of the 2030 Agenda (Russian Union of Industrialists and Entrepreneurs 2018). This approach is 
reflected in the company reports on CSR, in which particular activities are associated with the appropriate SDGs.

Despite Russia's economic decline, socially responsible projects should remain a priority for Russian corporations in the light of the environmental and social goals stipulated by the SDGs. This concerns not only the classic polluting companies, represented in the mining and manufacturing sectors, but also the businesses working in the services sector. Moreover, the development footprint of Russian business could be strengthened with governmental support, which is associated with PPP projects and political risk-reduction. Such cooperation is associated not only with a straightforward scale effect but also with long-lasting systemic changes.

\subsection{CONCLUSIONS}

In spite of the decline of the Russian economy and the instability of international relations with the United States and the EU since 2014, the government continues to develop its practices in the field of development assistance. As a result, it is impressive that Russia's commitment to international agreements remains solid, even as political actions, such as Western sanctions, push Russia into a more isolated position. Moreover, the government is trying to address the current challenges associated with both scale and change, such as the volumes of ODA provision, aid effectiveness, achievement of the SDGs, and business participation. ${ }^{6}$ Thus, Russia's contribution to systemic change and the scale thereof may be associated with the factors against which the effectiveness and efficiency of its ODA politics may be assessed. However, the absence of an ODA M\&E system at the national level makes it quite difficult to trace the progress.

The "scale-up" and "systemic change" theoretical approaches suggested for this chapter helped to reveal the modality of Russia's ODA provision. Russia has been incrementally increasing the volume of its ODA since it agreed to broaden the "scale" of the programmes and the number of regions covered by its ODA policy in its ODA Concept 2014. However, there is still a lack of evidence to help judge the "systemic change" of Russia's current efforts and results in the field of international development. The reason for this is the absence of a national ODA M\&E system. The issues of Russia's ODA accountability commitment, along with problems about its effectiveness and efficiency, make the task of forming it even more urgent.

Moving forward with the establishment of a national ODA M\&E system may result in more bureaucracy for decision-makers and implementers of ODA projects. However, the formation of such a system will help in solving other tasks related to the fulfilment of Russia's international obligations, including the achievement of the SDGs. In addition, it would inspire Russian businesses to become more significant development actors. Moreover, the concept of contested cooperation helps in assessing the current position of Russia as an international donor. On the one hand, Russia's ODA system is underdeveloped in comparison with other DAC countries. Cooperation with the DAC 
remains at quite a low level-Russia only reports to the DAC. On the other hand, Russia is also not a Global South country and has been isolated by the West from taking part in the fora of global donors, such as the G7 and G8 summits. This position requires the Russian government to look for other options for ODA system development.

As was revealed in the beginning, Russian development cooperation is often associated with contested cooperation, given the existing competition among national institutions over the implementation of Russian ODA. This is in addition to its activities that seek to shift the existing balance of international systems towards a new institutional order for development through the establishment of new institutions. The implementation of a new approach to Russia's foreign policy since 2014 (Concept of Foreign Politics) often implies the establishment of a new international institution as a way to challenge the existing system. Thus, the contested form of Russian development cooperation contributes to a proliferation of international institutions with the establishment of the New Development Bank and the Asian Infrastructure Investment Bank, as well as to the development of new national institutional practices that could contribute to aid effectiveness. Launching and operationalising an ODA M\&E system as well as cooperating with private business would lead to increases in aid efficiency as well, which could lead to direct and indirect systemic changes in Russia's aid programmes and development results.

\section{Notes}

1. Official development assistance(ODA flows) is defined as flows to countries and territories on the DAC list of ODA recipients and multilateral development institutions as follows: (1) they are provided by official agencies, including state and local governments, or by their executive agencies; (2) each transaction is (a) administered with the promotion of the economic development and welfare of developing countries as its main objective; and (b) is concessional in character. For more details, see: https://www.oecd.org/dac/stats/officialdevelopmentassis tancedefinitionandcoverage.htm.

2. This is according to outputs of the seminar "Towards the M\&E Framework for Russian Development Aid", held by the World Bank on 15 March 2016 in Moscow.

3. The issues of international development assistance are currently being discussed at the governmental commission on economic development and integration (Governmental Commission 2019).

4. This is according to outputs of the seminar "Towards the M\&E Framework for Russian Development Aid", held by the World Bank on 15 March 2016 in Moscow.

5. Of the 244 SDG indicators, 19 indicators ( 7 per cent) are in the process of development, 69 (28 per cent) are being developed, and 156 (71 per cent) are not being developed.

6. This is according to outputs of the seminar "Towards the M\&E Framework for Russian Development Aid", held by the World Bank on 15 March 2016 in Moscow. 
Annex A. Distribution of Russian bilateral assistance BY RECIPIENT COUNTRIES IN 2OI2-2OI7 (\$ MILLIONS)

\begin{tabular}{|c|c|c|c|c|c|c|}
\hline Aid allocation & 2012 & 2013 & 2014 & 2015 & 2016 & 2017 \\
\hline Bilateral aid (total) & 214.71 & 361.85 & 660.29 & 902.14 & 762.06 & 733.77 \\
\hline Afghanistan & 0.45 & 0 & 4.95 & 2.56 & 0.04 & 0.04 \\
\hline Armenia & 5.79 & 5.26 & 5.86 & 37.37 & 40.33 & 15.63 \\
\hline Azerbaijan & 1.73 & - & 0.48 & 0.01 & 0.05 & 2.49 \\
\hline Belarus & 0.11 & 1.47 & 2.5 & 2.97 & 2.87 & 2.25 \\
\hline Burundi & 0.14 & - & - & - & - & 0.04 \\
\hline Cambodia & 0.09 & - & - & - & 0.15 & 0.37 \\
\hline Congo & 0.28 & - & - & 1.21 & - & 1 \\
\hline Cuba & 5.58 & 2.76 & 176.98 & 351.97 & 352 & 353.83 \\
\hline DPRK & 15.5 & 33.61 & 68.42 & 59.77 & 58.63 & 57.71 \\
\hline Egypt & 0.07 & - & - & 0.78 & - & 0.03 \\
\hline Fiji & - & - & 0.13 & - & 0.02 & 0.01 \\
\hline Guinea & 0.97 & - & 16.79 & 6.25 & 6.32 & 3.72 \\
\hline India & 0.06 & 0.01 & - & - & 0.38 & 0.46 \\
\hline Iran & 0.1 & - & 1.3 & 1.3 & - & - \\
\hline Iraq & 0.41 & 0.55 & 1.07 & 0.23 & 1.58 & 1.59 \\
\hline Jordan & 2.6 & 5.44 & 3 & 4.99 & 0.5 & 1.67 \\
\hline Kazakhstan & 1.6 & 0.08 & 0.55 & 0.57 & 0.32 & 0.48 \\
\hline Kenya & 2.88 & 2.19 & 2 & - & - & 1 \\
\hline Kiribati & - & - & - & - & - & 0.01 \\
\hline Kyrgyzstan & 37.92 & 76.73 & 202.87 & 322.81 & 198.81 & 129.81 \\
\hline Laos & 0.23 & - & - & - & - & 0.17 \\
\hline Madagascar & 0.06 & - & - & - & 9.89 & 8.89 \\
\hline Marshall Islands & - & - & - & - & - & 0.01 \\
\hline Mongolia & 7.92 & 0.01 & - & 0.23 & 0.21 & 1.16 \\
\hline Morocco & 0.08 & 1.98 & 1.5 & 0.6 & - & 4.16 \\
\hline Mozambique & 0.09 & 13.05 & 8 & 8 & 8 & 8 \\
\hline Myanmar & - & - & 0.05 & 0.08 & - & 0.17 \\
\hline Namibia & 0.09 & 0.46 & - & 0.06 & - & 1.5 \\
\hline Nepal & 0.18 & - & - & - & 0.2 & 0.25 \\
\hline Nicaragua & 10.86 & 36.4 & 17.24 & 5.56 & 12.04 & 14.01 \\
\hline Palau & - & - & - & - & - & 0.01 \\
\hline Peru & - & - & - & - & - & 0.4 \\
\hline Serbia & 9.49 & 36.47 & 16.21 & 11.25 & 11.7 & 6.87 \\
\hline Somali & 2.04 & 1 & 1 & - & 1 & 1 \\
\hline Sudan & 0.01 & 2.56 & 0.05 & 1.54 & 0.01 & 1 \\
\hline Syria & 11.17 & 12.95 & 7.33 & 22.1 & 4 & 20.53 \\
\hline Tajikistan & 15.21 & 17.12 & 19.48 & 21.76 & 13.66 & 16.1 \\
\hline Tanzania & 0.07 & 3.37 & 1.37 & 1.37 & 1.37 & 1.37 \\
\hline Tonga & - & - & - & - & - & 0.01 \\
\hline Tunis & 0.04 & 1.98 & 1.65 & 1.12 & - & 5.66 \\
\hline Ukraine & 1.15 & 0.69 & 6.82 & - & 5.62 & 5 \\
\hline
\end{tabular}


(continued)

\begin{tabular}{lcccccc}
\hline Aid allocation & 2012 & 2013 & 2014 & 2015 & 2016 & 2017 \\
\hline Uzbekistan & 0.92 & 0.34 & 1.15 & 0.52 & 0.05 & 2.98 \\
Vietnam & 2.56 & 0.4 & - & 0.16 & 0.2 & 6.93 \\
Yemen & 1.5 & - & 0.36 & 2.36 & - & 1 \\
\hline
\end{tabular}

Source Based on data provided by the OECD-DAC and the MoF of Russia (Knobel and Zaytsev 2018)

\section{REFERENCES}

Agreement between Cuba and Russia. (2013). Agreement on the settlement of the debt of the Republic of Cuba to the Russian Federation on loans extended in the period of the former USSR, signed on October 25, 2013. http://asozd2.duma.gov.ru/addwork/scans.nsf/ID/31D1C5D3E102 245F43257D0A0052720C/\$FILE/560637-6.PDF? OpenElement (in Russian).

Bartenev, V., \& Glazunova, E. (2013). International development cooperation: Set of lectures. Moscow: World Bank.

Belarus received from Russia a loan of $\$ 700$ million dollars. (2017, September 15). Ukrop News 24. https://ukropnews24.com/belarus-received-from-russia-a-loan-of700-million/.

Bobylev, S. N., \& Grigoriev, L. M. (2015). The UN Sustainable Development Goals and Russia: Human Development Report in the Russian Federation. http://ac.gov. $\mathrm{ru} /$ files/publication/a/11068.pdf (in Russian).

Boehmer, H. M., \& Zaytsev, Y. (2018). Monitoring and evaluation in Russia's international development assistance program. Research paper for the 13-Biannual conference of the European Evaluation Society (EE18-0036). https://papers.ssrn. com/sol3/papers.cfm?abstract_id=3360461.

Boehmer, H. M., \& Zaytsev, Y. (2019). Raising aid efficiency with ODA M\&E systems. Journal of MultiDisciplinary Evaluation, 15(32), 28-36.

Central Bank of the Russian Federation. (2018). Statistics of the Bank of Russia. https://cbr.ru/eng/statistics/.

Chief Executives for Corporate Purpose. (2016). Giving around the globe: 2016 edition. https://cecp.co/wp-content/uploads/2016/11/2016_Giving_Aro und_the_Globe_web-1.pdf.

Eurasian Development Bank. (2017). Eurasian fund for stabilization and development (Annual report). https://efsd.eabr.org/upload/iblock/c5b/EABR_AR_2 017_EFSD_EN-_1_.pdf.

Federal Customs Service. (2018). Customs statistics of external trade. Moscow: Author (in Russian).

Governmental Commission. (2019). Governmental commission on economic development and integration. Moscow: Government of Russia (in Russian).

Harich, J. (2010). Change resistance as the crux of the environmental sustainability problem. System Dynamics Review, 26(1), 35-72. 
Humphrey, J., Spratt, S., Thorpe, J., \& Henson, S. (2014). Understanding and enhancing the role of business in international development: A conceptual framework and agenda for research (IDS Working Paper 440). Brighton: Institute of Development Studies.

Knobel, A., \& Zaytsev, Y. (2017). Russia's economic aid to other countries in 2016. Economic Development of Russia, 24(10), 17-21 (in Russian).

Knobel, A., \& Zaytsev, Y. (2018). Russia as international donor in 2017. Economic Development of Russia, 25(12), 8-12 (in Russian).

Knobel, A., Lipin, A., Malokostov, A., Tarr, D. G., \& Turdyeva, N. (2019). Deep integration in the Eurasian economic union: What are the benefits of successful implementation or wider liberalization? Eurasian Geography and Economics, 60(2), $177-210$.

Larionova, M. (2007). G8 compliance with commitments, made at 2006 summit in St. Petersburg. International Organizations Research Journal, 2(3), 34-80 (in Russian).

Lukoil Overseas. (2011). Annual report 2011. http://www.lukoil.com/FileSystem/ 9/289069.pdf.

Ministry of Finance. (2013). Presentation on the mechanism of using the special account funds for the purpose of financing supplies, works and services as part of projects in the Republic of Cuba in accordance with the Russian-Cuban Intergovernmental Agreement of October 25, 2013. Moscow: Author.

MoFA RF (Ministry of Foreign Affairs of the Russian Federation). (2007, June 14). The concept of Russia's participation in international development assistance (No. Pr-1040). https://www.minfin.ru/common/img/uploaded/library/2007/06/con cept_eng.pdf.

MoFA RF. (2014, April 20). The concept of the Russian Federation's state policy in the area of international development assistance (PR-No. 259). http://minfin.ru/com mon/upload/library/2007/06/concept_eng.pdf.

Montreal Protocol. (1987, September 16). Montreal Protocol on ozone depleting substances. http://www.un.org/ru/documents/decl_conv/conventions/montreal_ prot.shtml.

OECD (Organisation for Economic Co-operation and Development). (2017). Development aid stable in 2017 with more sent to poorest countries. https://www.oecd. org/development/development-aid-stable-in-2017-with-more-sent-to-poorest-cou ntries.htm.

OECD. (2019). The 0.7\% ODA/GNI target-A history. http://www.oecd.org/dac/ stats/the07odagnitarget-ahistory.htm.

Order of the Government of the Russian Federation. (2017). On ensuring coordination of activities of subjects of official statistics on the formation and submission to international organizations of national statistical information on indicators of achievement of the Sustainable Development Goals (No. 1170-p). http://docs.cntd.ru/document/ 436740030 (in Russian).

Presidential Press and Information Office. (2016, December 27). Meeting of the State Council on the issue "on the environmental development of the Russian Federation in the interests of future generations". http://kremlin.ru/events/president/news/ 53602 (in Russian).

Presidential Press and Information Office. (2018, March 7). Decree of the president of the Russian Federation on national goals and strategic tasks of the development of the Russian Federation for the period up to 2024. http://www.kremlin.ru/acts/bank/ 43027 (in Russian). 
RAS Institute. (2014). Investment from Russia stabilizes after the global crisis. Moscow: RAS Institute of World Economy and International Relations.

Resolution of the Government of the Russian Federation. (2017). Formation of offcial statistical information carried out by subjects of official statistical accounting (Resolution No. 2033-r). Moscow: Government of Russia (in Russian).

Rosstat (Russian Federal State Statistics Service). (2015). Sustainable Development Goals. Moscow: Author (in Russian).

Rosstat. (2019). Status of developing indicators for Sustainable Development Goals. Moscow: Author (in Russian).

Ruffer, T., \& Wach, E. (2013). Review of M4P evaluation methods and approaches (ITAD Report). Hove: Itad.

Rusal. (2013a). Sustainable development report. http://www.rusal.ru/upload/uf/ ecd/EWF\%20101.pdf (in Russian).

Rusal. (2013b). Social programs abroad: Sustainability report of UC "Rusal". http:// sr.rusal.ru/investments-in-development-of-local-communities/the-results-of-201 2.php (in Russian).

Russia and the United States refused to participate in the recapitalization of the World Bank. (2018, April 22). RBC. Moscow: RBC Group (in Russian).

Russia has written off Kyrgyzstan's debt of USD240 million. (2017, May 4). UAWire. https://www.uawire.org/news/russia-has-written-off-kyrgyzstan-sdebt-of-240-million-usd.

Russian Union of Industrialists and Entrepreneurs (2018). Russian business and Sustainable Development Goals. http://media.rspp.ru/document/1/b/2/b24091 d44c9660fcf3a9fdad6551b88f.pdf (n Russian).

Sineva, O. (2018, July 11). In South Ossetia, a surgical complex was built at the expense of the Russian budget. https://vademec.ru/news/2018/07/11/v-yuzhnoy-osetiiotkryli-medkompleks-za-schet-finansovoy-pomoshchi-rossii/ (in Russian).

The volume of Russian assistance to developing countries in 2017 exceeded $\$ 1.2$ billion. (2018, April 24). Central Asian. https://www.centralasian.org/a/291 89917.html (in Russian).

Thorpe, J. (2014). Business and international development: Is systemic change part of the business approach? https://opendocs.ids.ac.uk/opendocs/bitstream/handle/ $123456789 / 4307 /$ ER92\%20Business\%20and\%20International\%20Development\% 20Is\%20Systemic\%20Change\%20Part\%20of\%20the\%20Business\%20Approach.pdf.

UN (United Nations). (2015). The United Nations 2030 Agenda for Sustainable Development. https://sustainabledevelopment.un.org/content/documents/ $21252030 \% 20$ Agenda\%20for\%20Sustainable\%20Development $\% 20$ web.pdf.

What assistance does Russia provide to Tajikistan? (2017, November 27). TAJWeek. http://news.tajweek.tj/view/kakuyu-pomosch-okazyvaet-rossiya-tadzhikistanu/ (in Russian).

World Bank. (2018). 2017 trust fund annual report. http://documents.worldbank. org/curated/en/428511521809720471/2017-trust-fund-annual-report.

World Bank. (2019). Russia and the World Bank: International development assistance. https://www.worldbank.org/en/country/russia/brief/international-development.

World Business Council for Sustainable Development. (2013). Scaling up inclusive business: Solutions to overcome internal barriers (WBCSD Brief). Conches-Geneva: Author. 
Zaytsev, Y. (2013). International development assistance programs in the context of supporting the investment activity of Russian business in developing countries: Opportunities and challenges. Problems of National Strategy, 5, 54-71 (in Russian). Zaytsev, Y. (2018). Social investments of Russian businesses abroad. International Trends, 16(3), 189-201 (in Russian).

Open Access This chapter is licensed under the terms of the Creative Commons Attribution 4.0 International License (http://creativecommons.org/licenses/by/4.0/), which permits use, sharing, adaptation, distribution and reproduction in any medium or format, as long as you give appropriate credit to the original author(s) and the source, provide a link to the Creative Commons license and indicate if changes were made.

The images or other third party material in this chapter are included in the chapter's Creative Commons license, unless indicated otherwise in a credit line to the material. If material is not included in the chapter's Creative Commons license and your intended use is not permitted by statutory regulation or exceeds the permitted use, you will need to obtain permission directly from the copyright holder.

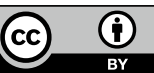

